STUDIA IURIDICA TORUNIENSIA

TOM TRZECI, DEBIUTY

pod red. Krystyny Kamińskiej, Toruń 2006

Marzena Szabłowska

\title{
Ochrona dóbr osobistych pracownika z perspektywy europeizacji polskiego prawa pracy
}

\author{
Ochrona dóbr osobistych w Polsce \\ - zarys problematyki ${ }^{* *}$
}

Generalne uregulowania w zakresie ochrony dóbr osobistych znajduja się w części ogólnej kodeksu cywilnego. Dokonując wykładni tychże przepisów nie unikniemy odwołań do konstytucyjnego systemu wartości ${ }^{1}$.

Zgodnie $\mathrm{z}$ art. 23 k.c., dobra osobiste pozostaja pod ochroną prawa cywilnego niezależnie od ochrony przewidzianej w innych przepisach. Nor-

* Na gruncie tego opracowania termin „europeizacja” [polskiego prawa pracy] będzie używany w znaczeniu szerszym. Rozważania nie ograniczą się tylko do problemów związanych z tzw. „uwspólnotowieniem” [polskiego prawa pracy], czyli zbliżaniem, harmonizowaniem, dostosowywaniem polskiego prawa [pracy] do reguł i wymagań prawa wspólnotowego. Będzie mowa także o standardach wyznaczanych przez normy tworzone w ramach Rady Europy.

** Ogólne postanowienia o ochronie dóbr osobistych znalazły się po raz pierwszy w polskim systemie prawnym dopiero po drugiej wojnie światowej, w związku z wejściem w życie ustawy z 18 VII 1950 r. - Przepisy ogólne prawa cywilnego, Dz.U. Nr 34, poz. 311.

${ }^{1} \mathrm{~W}$ literaturze przedmiotu podkreśla się, że wejście $\mathrm{w}$ życie Konstytucji $\mathrm{z}$ dnia 2 kwietnia 1997 r., zawierającej unormowania w zakresie praw i wolności osobistych, wywarło wpływ na rozwój ochrony dóbr osobistych w Polsce. Akcentuje się jednocześnie, że oddziaływanie ustawy zasadniczej $\mathrm{w}$ obszarze prawa prywatnego $\mathrm{z}$ reguły nie polega na tworzeniu praw podmiotowych. W związku z tym powództwa o ochronę dóbr osobistych będą opierały się przede wszystkim na przepisach kodeksu cywilnego. Por. m.in.: S. Dmowski, S. Rudnicki, Komentarz do kodeksu cywilnego. Ksiega pierwsza (Część ogólna), Warszawa 2001, s. 81; M. Safjan, Refleksje wokót konstytucyjnych uwarunkowań rozwoju ochrony dóbr osobistych, Kwartalnik Prawa Prywatnego 2002, z. 1, s. 224; J. Chaciński, Prawa podmiotowe a ochrona dóbr osobistych, Lublin 2004, s. 156-162. 
ma ta wypowiada dwie idee. Po pierwsze, akcentuje zasadę ochrony dóbr osobistych przez prawo cywilne. Po drugie, statuuje koncepcję, wedle której ochrona przewidziana $w$ innych gałęziach prawa nie wyłącza ochrony cywilnoprawnej ${ }^{2}$.

W art. 23 k.c. ustawodawca dokonał tylko przykładowego wyliczenia dóbr osobistych ${ }^{3}$. Posłużenie się przez ustawodawcę zwrotem „w szczególności" świadczy o tym, że katalog dóbr osobistych jest otwarty. W związku $\mathrm{z}$ taką redakcją art. 23 k.c. sąd jest zobligowany do objęcia ochroną także dóbr osobistych niewskazanych w ustawie (w przypadku ich naruszenia lub zagrożenia) ${ }^{4}$.

Katalog dóbr osobistych powiększa się w związku z wykładnią przepisów dokonywaną przez przedstawicieli doktryny i judykatury. Tendencja ta stanowi nie tylko wyraz wzrastającego uznania dla osoby ludzkiej, ale jest zarazem odpowiedzią na zagrożenia dóbr osobistych wywołane rozwojem nauki, techniki czy środków masowego przekazu. Należy podkreślić, że ważną podstawę do uznania pewnych wartości za dobra osobiste stanowią przepisy konstytucji o prawach i wolnościach człowieka i obywatela, a także konwencje międzynarodowe ${ }^{5}$, wśród których szczególne znaczenie należy przypisać Konwencji o Ochronie Praw Człowieka i Podstawowych Wolności (1950 r.) ${ }^{6}$ oraz Międzynarodowym Paktom Praw Człowieka (1977 r.).

W doktrynie przeważa pogląd, że dobra osobiste są chronione za pomocą konstrukcji praw (podmiotowych) osobistych ${ }^{7}$. Wskazując na cechy cha-

2 A. Wolter, Prawo cywilne. Zarys części ogólnej, Warszawa 1998, s. 184.

${ }^{3} \mathrm{~W}$ doktrynie prawa cywilnego dominuje pogląd, że pojęcie „dobro osobiste" powinno być definiowane w odniesieniu do kryteriów obiektywnych. Zgodnie $z$ tym poglądem akceptacja przez system prawny jest konieczna, aby daną wartość uznać za dobro osobiste. Por. m.in.: Z. Radwański, Prawo cywilne - część ogólna, Warszawa 2003, s. 152; A. Szpunar, Ochrona dóbr osobistych, Warszawa 1979, s. 106. Odmienne stanowisko reprezentuje S. Grzybowski (por.: S. Grzybowski, Ochrona dóbr osobistych wedtug przepisów ogólnych prawa cywilnego, Warszawa 1957, s. 19) oraz A. Wolter (por.: A. Wolter, op.cit., s. 182). Opowiadają się oni za definiowaniem pojęcia „dobro osobiste” w odniesieniu do kryteriów subiektywnych, a co za tym idzie za uznaniem „dobra osobistego" za pojęcie pozaprawne.

${ }^{4}$ P. Sut, Problem twórczej wyktadni przepisów o ochronie dóbr osobistych, Państwo i Prawo (dalej PiP) 1997, z. 9, s. 30.

${ }^{\mathrm{Z}}$ Z. Radwański, op.cit., s. 153.

${ }^{6}$ Przystapienie Polski do tej konwencji jest faktem doniosłym z punktu widzenia „europeizacji prawa polskiego" (szeroko rozumianej). Wiąże się ono bowiem nie tylko z zaakceptowaniem standardów wyrażonych w jej treści, ale także z poddaniem judykatury polskiej kontroli sprawowanej przez Europejski Trybunał Praw Człowieka, a co za tym idzie przyjęciem dorobku Trybunału.

${ }^{7}$ Por. m.in.: Z. Radwański, Koncepcja praw podmiotowych osobistych, Ruch Prawniczy, Ekonomiczny i Socjologiczny 1988, z. 2, s. 2 i n. Odmienny pogląd jest prezentowany przez B. Gawlika. Jego zdaniem dobra osobiste nie mogą być chronione za pomocą kon- 
rakterystyczne tych praw podmiotowych, podkreśla się, że są to prawa bezwzględne, ponadto niemajątkowe, niezbywalne i niedziedziczne.

\section{Prawa podmiotowe służące ochronie dóbr osobistych pracownika}

Jeśli chodzi o ochronę dóbr osobistych pracownika, wiele kontrowersji budzi kwestia, czy prawa podmiotowe zapewniające ochronę dobrom osobistym pracownika mają charakter bezwzględny, podobnie jak prawa (podmiotowe) osobiste na gruncie przepisów prawa cywilnego, czy też należy je uznać za prawa (podmiotowe) względne.

Tezę o względnym charakterze prawa pracownika do poszanowania jego godności wysunął J. Jończyk (obowiązywał wówczas art. 449 kodeksu zobowiązań). Należy podkreślić, że J. Jończyk odróżnił „godność pracowniczą" od „godności”. Jego zdaniem „godność pracownicza” jako rodzaj dobra osobistego ma swój sens w dość ograniczonym kręgu osób, a mianowicie w środowisku, w którym ktoś występuje przede wszystkim w roli pracownika. Mając to na uwadze, należy uznać, że prawo do poszanowania godności pracowniczej ma charakter względny ${ }^{8}$.

Do koncepcji J. Jończyka, sformułowanej w latach sześćdziesiątych, nawiązał już pod rządami art. 23 i 24 k.c. M. Dyczkowski. Jego zdaniem, skoro treścia prawa do poszanowania godności pracownika są z jednej strony obowiązki pracodawcy, a $z$ drugiej strony uprawnienia pracownika, to ewidentnie mamy do czynienia $\mathrm{z}$ prawem podmiotowym względnym, a więc z prawem podmiotowym skutecznym względem określonego podmiotu stosunku prawnego - względem pracodawcy ${ }^{9}$.

Pogląd J. Jończyka oraz M. Dyczkowskiego o względnym charakterze praw podmiotowych służących ochronie dóbr osobistych pracownika należy uznać za odosobniony. Większość przedstawicieli doktryny (zarówno zwolenników monistycznej, jak i pluralistycznej koncepcji dóbr osobistych) jest zdania, że prawa te mają charakter bezwzględny. Takie stanowisko zajmują m.in. J. A. Piszczek oraz I. Boruta.

strukcji praw podmiotowych osobistych, a jedynie poprzez powszechnie obowiazujący system nakazów i zakazów. Por. B. Gawlik, Ochrona dóbr osobistych, sens i nonsens koncepcji tzw. praw podmiotowych osobistych, Zeszyty Naukowe Uniwersytetu Jagiellońskiego. Prace z Wynalazczości i Ochrony Własności Intelektualnej 1985, z. 41.

8 J. Jończyk, Zagadnienia ochrony dóbr osobistych w prawie pracy, PiP 1963, z. 5-6, s. 819 .

${ }^{9}$ M. Dyczkowski, W sprawie ochrony dóbr osobistych pracowników, Praca i Zabezpieczenie Społeczne (dalej PiZS) 2001, nr 5, s. 10 i n. 
Jan A. Piszczek stwierdził, że prawo do ochrony godności pracowniczej, wynikającej z ogólnego prawa osobistości, jest prawem podmiotowym bezwzględnym $^{10}$. Jego pogląd $w$ kwestii bezwzględnego charakteru praw podmiotowych służących ochronie dóbr osobistych pracownika podziela I. Boruta, chociaż przyjmuje ona pluralistyczną koncepcję dóbr osobistych ${ }^{11}$.

Na tym etapie rozważań, mając na uwadze powyższe ustalenia, można postawić tezę, że prawa podmiotowe służące ochronie dóbr osobistych pracownika mają charakter bezwzględny, podobnie jak prawa osobiste na gruncie prawa cywilnego. Nieuzasadnione wydaje się bowiem konstruowanie pracowniczych praw osobistych jako kategorii odrębnej od praw osobistych służących ochronie dóbr osobistych człowieka. Należy jednak pamiętać o tym, że nawiązanie stosunku pracy wpływa na zakres ochrony dóbr osobistych $^{12}$ oraz o tym, że pracownik (w rozumieniu art. 2 k.p.) może poszukiwać ochrony godności i innych dóbr osobistych nie tylko na gruncie prawa cywilnego, ale i na gruncie prawa pracy. Nawiązanie umownego czy też pozaumownego stosunku pracy stwarza bowiem po stronie pracodawcy obowiązki w zakresie ochrony dóbr osobistych pracownika, a z tymi obowiązkami pracodawcy związane są korelatywnie uprawnienia pracownika.

\section{Obowiązki pracodawcy \\ w zakresie szanowania dóbr osobistych pracownika}

\section{Generalny obowiązek szanowania godności oraz innych dóbr osobistych pracownika}

Pracodawca jest obowiązany szanować godność oraz inne dobra osobiste pracownika $^{13}$. Wprowadzenie tego obowiązku do kodeksu pracy w $1996 \mathrm{r}^{14}$

10 J. A. Piszczek, Cywilnoprawna ochrona godności pracowniczej, Toruń 1981, s. 47-48.

11 I. Boruta, Ochrona dóbr osobistych pracownika, PiZS 1998, nr 2, s. 19-20.

$12 \mathrm{~W}$ doktrynie zachodnioniemieckiej już $w$ latach pięćdziesiątych minionego wieku zwracano uwagę, że zawarcie umowy o pracę powoduje pewne ograniczenia w zakresie ochrony dóbr osobistych pracownika związane $z$ procesem pracy, np. poprzez podporządkowanie pracownika poleceniom pracodawcy. Podkreśla się jednak, że te ograniczenia muszą znajdować swe oparcie bądź w wykonywaniu przez pracodawce jego praw podmiotowych (wynikających $z$ umowy o pracę), bądź na innej podstawie wyłączającej w konkretnym przypadku bezprawność (np. zgoda). Por. A. Dyoniak, $Z$ problematyki ochrony dóbr osobistych pracownika w prawie polskim $i$ RFN, Studia Prawnicze 1991, z. 1, s. 24. Należy zauważyć, że w Polsce problem wpływu nawiązania stosunku pracy na zakres ochrony dóbr osobistych pracownika, w ujęciu in abstracto, nie doczekał się jeszcze szerszych opracowań.

${ }^{13}$ Por. art. $11^{1}$ k.p.

${ }^{14}$ Por. art. 1 pkt 12 ustawy z 2 II 1996 r. o zmianie ustawy - Kodeks pracy oraz o zmianie niektórych ustaw, Dz.U. Nr 24, poz. 110. 
uważane jest za wyraz percepcji zasad proklamowanych w konwencjach Międzynarodowej Organizacji Pracy, w których przywiazzuje się szczególną wage do poszanowania godności, a także innych dóbr osobistych pracownika ${ }^{15}$.

Obowiązek szanowania godności i innych dóbr osobistych pracownika to jedna $\mathrm{z}$ podstawowych zasad prawa pracy, nie tylko polskiego ${ }^{16}$. Należy przyjąc, że zasada ta ma zarazem postulatywny, jak i normatywny charakter. Wyraża ona bowiem adresowany zarówno do pracodawców, jak i do organów tworzących i stosujących prawo postulat nieinstrumentalnego traktowania człowieka w procesie pracy, a poza tym nakłada na pracodawców obowiązki w zakresie ochrony godności i innych dóbr osobistych pracownika ${ }^{17}$.

Zdaniem T. Zielińskiego podstawowa zasada prawa pracy zawarta $\mathrm{w}$ art. $11^{1}$ k.p. została sformułowana zbyt lakonicznie. Podkreśla on, że art. $11^{1}$ k.p. powinien wyraźnie określać przedmiot ochrony ${ }^{18}$. Ustawodawca ograniczył się bowiem do wskazania, że pracodawca jest obowiązany szanować godność i inne dobra osobiste pracownika, nie wymieniając nawet przykładowo tych innych dóbr osobistych.

$\mathrm{W}$ treści art. $11^{1}$ k.p. zaakcentowano, że pracodawca obowiązany jest szanować godność pracownika ${ }^{19}$. Wydaje się, że termin "godność”, użyty w art. $11^{1}$ k.p., należy rozumieć w sposób zbliżony do czci, uznanej za jedno $\mathrm{z}$ dóbr osobistych w art. 23 k.c. ${ }^{20}$ Przemawia za tym chociażby wykładnia gramatyczna przepisu, ustawodawca posłużył się bowiem sformułowaniem "godność i inne dobra osobiste".

Analizując treść art. $11^{1}$ k.p., nie sposób nie zauważyć, że przepis ten nakłada na pracodawcę nie tylko obowiązek „nienaruszania” dóbr osobistych pracownika. Pracodawca jest zobowiązany ponadto do podejmowania działań, mających na celu stworzenie warunków, w których dobra osobiste

${ }^{15}$ M. T. Romer, Prawo pracy. Komentarz, Warszawa 2000, s. 60.

${ }^{16} \mathrm{~W}$ niemieckim prawie pracy przyjmuje się istnienie po stronie pracodawcy obowiązku pieczy nad pracownikiem (Fürsorgepflicht). Obowiązek ten zawiera także zobowiązanie pracodawcy do uwzględniania usprawiedliwionych, niematerialnych interesów pracownika, przez co rozumie się również respektowanie prawa osobistości pracownika. Por. A. Dyoniak, op.cit., s. 24.

${ }^{17}$ I. Boruta, Godność człowieka - kategoria prawa pracy, PiZS 2001, nr 8, s. 2-3.

18 T. Zieliński, Zasady prawa pracy w nowym systemie ustrojowym, PiP 2001, z. 2, s. 7.

19 Problem szanowania godności człowieka w procesie pracy należy uznać za zagadnienie interdyscyplinarne. Jest on eksponowany w nauczaniu społecznym Kościoła (por. m.in.: Jan Paweł II, Encyklika Laborem exercens, [w:] Encykliki i adhortacje 1979-1981, Warszawa 1983; Orędzie Jana Pawta II do świata pracy, opubl.: Niedziela 2000, nr 20, s. 5), a także w literaturze z zakresu zarządzania. Por. m.in. A. Szałkowski, Wymiar etyczny zarzqdzania personelem, PiZS 1996, nr 1, s. 16 i n.

20 A. Drozd, O dopuszczalności wykorzystywania wariografu $w$ stosunkach pracy, PiZS 2003, nr 4, s. 9-10. 
pracownika nie będą naruszane ${ }^{21}$. Ustawodawca nałożył na pracodawcę obowiązek szanowania (godności i innych dóbr osobistych pracownika), a szanowanie to nie tylko poważanie, nienaruszanie, ale także ochranianie przed naruszeniem ${ }^{22}$.

Należy podkreślić, że ustawodawca w art. $11^{1}$ k.p. ustanowił jedynie obowiązek pracodawcy, nie określił zaś sankcji, gdy zachowanie pracodawcy jest sprzeczne $\mathrm{z}$ tym obowiązkiem ${ }^{23}$. A $\mathrm{z}$ takimi zachowaniami będziemy mieli do czynienia zarówno w sytuacji, gdy pracodawca swoim działaniem (zaniechaniem) narusza określone dobro osobiste pracownika, jak i wówczas, gdy pracodawca uchybia obowiązkowi stworzenia warunków, w których dobra osobiste pracownika nie będą naruszane przez osoby trzecie, przede wszystkim przez innych pracowników.

Poza generalnym obowiązkiem szanowania godności oraz innych dóbr osobistych pracownika, sformułowanym $\mathrm{w}$ art. $11^{1} \mathrm{k} . \mathrm{p}$., przepisy prawa pracy nakładają na pracodawcę szczegółowe obowiązki w tym zakresie. Uregulowania te uwzględniają specyfikę naruszeń (zagrożeń) dóbr osobistych pracownika $\mathrm{w}$ miejscu pracy lub $\mathrm{w}$ związku $\mathrm{z}$ praca. $\mathrm{W}$ przeciwieństwie do art. $11^{1}$ k.p., przepisy te najczęściej nie tylko proklamują obowiązki pracodawcy, ale i ustanawiają sankcje za zachowania sprzeczne $\mathrm{z}$ tymi obowiązkami.

\section{Szczególowe obowiązki pracodawcy w zakresie szanowania dóbr osobistych pracownika}

W niniejszym opracowaniu omówione zostaną tylko niektóre ze szczegółowych obowiązków pracodawcy w zakresie szanowania dóbr osobistych pracownika. Przy okazji prezentowania obowiązków pracodawcy w zakresie przeciwdziałania molestowaniu seksualnemu i mobbingowi oraz obowiązków w zakresie ochrony interesów i praw pracownika, którego dane są przetwarzane w związku z zatrudnieniem, zaakcentowane zostanie zjawisko europeizacji polskiego prawa pracy oraz zmiany w przepisach statuujacych te obowiązki, wprowadzone w związku $z$ ostatnią nowelizacją kodeksu pracy.

21 M. Dyczkowski, op.cit., s. 10.

22 Por. hasło „Szanować” w: Stownik języka polskiego, pod red. M. Szymczaka, t. 3, Warszawa 1993, s. 393.

${ }^{23}$ Zdaniem T. Zielińskiego, sprzeczne $\mathrm{z}$ obowiązkiem szanowania godności i innych dóbr osobistych pracownika zachowanie pracodawcy powinno być w kodeksie pracy w sposób wyraźny uznane za ciężkie naruszenie podstawowych praw pracownika ( $w$ rozumieniu art. $55 \S 1^{1}$ k.p.). Por. T. Zieliński, op.cit., s. 11. 


\section{Obowiązki pracodawcy \\ w zakresie przeciwdzialania molestowaniu seksualnemu}

Molestowanie $^{24} \mathrm{w}$ miejscu pracy (sexual harassment) może przybierać dwie podstawowe formy. Pierwsza z nich to tzw. seksualny szantaż (sexual blackmail), druga zaś jest określana jako stworzenie nieprzyjaznych (wrogich) warunków pracy (creation of a hostile working environment). Sprawcą szantażu seksualnego może być jedynie pracodawca lub osoba reprezentująca pracodawcę. Jeżeli chodzi o molestowanie seksualne, które polega na stworzeniu nieprzyjaznych (wrogich) warunków pracy, to jego sprawca może być każdy, aczkolwiek najczęściej jest nim współpracownik ofiary ${ }^{25}$. W związku z zakwalifikowaniem określonego zachowania jako przejawu molestowania seksualnego pojawiają się liczne wątpliwości. To samo zachowanie może być postrzegane jako „flirtowanie” lub przeciwnie - jako „sprawianie przykrości”26. Wydaje się, że więcej problemów pojawia się, gdy mamy do czynienia $\mathrm{z}$ molestowaniem seksualnym, które polega na stworzeniu nieprzyjaznych (wrogich) warunków pracy.

Problem molestowania seksualnego w miejscu pracy (lub w związku z praca) przestał być zjawiskiem skrywanym. Coraz więcej uwagi poświęca się stworzeniu instrumentów prawnych, które skutecznie przeciwdziałałyby molestowaniu seksualnemu w miejscu pracy. Wiąże' się to $z$ dążeniem do zapewnienia godnych warunków pracy oraz do wyeliminowania instrumentalnego traktowania pracownika. Trudno tu przecenić rolę Międzynarodowej Organizacji Pracy.

Wprawdzie żadna z konwencji Międzynarodowej Organizacji Pracy nie formułuje wprost zakazu molestowania seksualnego, jednak zakaz ten jest wyprowadzany z postanowień Konwencji nr 111 dotyczącej dyskryminacji w zakresie zatrudnienia i wykonywania zawodu ${ }^{27}$. Molestowanie seksualne

${ }^{24}$ Termin „molestowanie” pochodzi z języka łaciński’ego od słowa molestia (por. hasło molestia w: Stownik tacińsko-polski, oprac. K. Kumaniecki, Warszawa 1997, s. 313). Stownik języka polskiego określa „molestowanie” jako natrętne proszenie o coś, nudzenie ciągłymi prośbami, naprzykrzanie się. Por. Stownik języka polskiego, pod red. M. Szymczaka, t. 2, Warszawa 1993, s. 203.

${ }_{25}$ J. Warylewski, Molestowanie seksualne w miejscu pracy, Sopot 1999, s. 20.

${ }^{26}$ E. Mandal, Molestowanie seksualne w miejscu pracy, Palestra 2002, nr 1-2, s. 81.

${ }^{27} \mathrm{Na}$ podstawie Konwencji nr 111 dotyczącej dyskryminacji w zakresie zatrudnienia i wykonywania zawodu Komisja Ekspertów do spraw przestrzegania Konwencji i zaleceń przedstawiła w raporcie z 1988 r. listę zachowań, które mogą być zakwalifikowane jako molestowanie seksualne. I tak za molestowanie seksualne mogą być uznane: zniewagi i obelgi, insynuacje, niestosowne uwagi na temat ubioru, uczesania, wieku, sytuacji rodzinnej, lubieżne spojrzenia, różnego rodzaju pieszczoty lub gest o konotacji seksualnej, wprowadzenie protekcjonalnych stosunków, które naruszają godność osobistą ofiary. Molestowanie seksualne może przybrać także formę opowiadania dowcipów lub prezentacji treści o cha- 
uznaje się bowiem za przejaw dyskryminacji ze względu na płeć. Dał temu wyraz Komitet ONZ do spraw likwidacji dyskryminacji kobiet.

Problem molestowania seksualnego $\mathrm{w}$ miejscu pracy lub $\mathrm{w}$ związku z pracą został dostrzeżony również przez Radę Europy. W art. 26 Zrewidowanej Europejskiej Karty Społecznej proklamowano prawo „wszystkich pracowników” do poszanowania ich godności w miejscu pracy, wskazując jednocześnie na konieczność przeciwdziałania zjawisku molestowania seksualnego w zatrudnieniu.

$Z$ kolei w przepisach prawa wspólnotowego nie tylko określono instrumenty mające na celu wyeliminowanie (ograniczenie) zjawiska molestowania seksualnego, ale i zdefiniowano pojęcia "molestowanie” oraz „molestowanie seksualne", co wymaga podkreślenia.

W myśl art. 2 Dyrektywy 2000/43/WE oraz art. 2 Dyrektywy 2000/78/WE, „molestowanie" to niepożądane zachowanie ze względu na płeć, rasę, pochodzenie etniczne, religię, przekonania, wiek czy też orientację seksualną; celem lub skutkiem tego zachowania jest naruszenie godności i stworzenie onieśmielającej, wrogiej, poniżającej, upokarzającej lub uwłaczającej atmosfery ${ }^{28}$.

Molestowanie seksualne jest podobnym zachowaniem o charakterze seksualnym $^{29}$. W Dyrektywie 2002/73/WE, zawierającej definicję „molestowania seksualnego", nie wyjaśniono jednak, co należy rozumieć przez zachowanie o charakterze seksualnym ${ }^{30}$. W art. 1 ust. 2 tejże dyrektywy wskazano jedynie, że za przejaw molestowania seksualnego może być uznane zachowanie werbalne, niewerbalne i fizyczne ${ }^{31}$. Należy podkreślić, że w świetle przepisów prawa wspólnotowego molestowanie seksualne jest uznawane za przejaw dyskryminacji ze względu na płeć. W ust. 8 preambuły do Dyrektywy 2002/73/WE znajduje się stwierdzenie, że molestowanie seksualne jest sprzeczne $\mathrm{z}$ zasadą równego traktowania kobiet i mężczyzn.

Polski ustawodawca, stawiając sobie za cel dostosowanie polskiego prawa pracy do wspólnotowych norm antydyskryminacyjnych, w tym do

rakterze pornograficznym. Por. J. Warylewski, Molestowanie seksualne $w$ miejscu pracy, PiP 1999, z. 3, s. 61.

${ }^{28}$ Dyrektywa Rady nr 2000/43/WE z 29 VI 2000 r. wprowadzająca zasadę równego traktowania osób bez względu na pochodzenie rasowe lub etniczne, Dz. Urz. WE L 180/22, art. 2 oraz Dyrektywa Rady nr 2000/78/WE z 27 XI 2000 r. ustanawiająca ogólne warunki ramowe równego traktowania w zakresie zatrudnienia i pracy, Dz.Urz. WE L 303/16, art. 2.

${ }_{30}^{29}$ L. Florek, Europejskie prawo pracy, Warszawa 2003, s. 66.

${ }^{30}$ I. Boruta, Ochrona przed nękaniem i molestowaniem seksualnym w zatrudnieniu, Praca i Zabezpieczenie Społeczne 2003, nr 8, s. 4.

${ }^{31}$ Dyrektywa Parlamentu Europejskiego i Rady nr 2002/73/WE z 23 IX 2002 r. zmieniająca Dyrektywę Rady 76/207/EWG w sprawie wprowadzenia zasady równego traktowania mężczyzn i kobiet w zakresie dostępu do zatrudnienia, kształcenia i awansu zawodowego oraz warunków pracy, Dz.Urz. UE L 269/15, art. 1 ust. 2. 
norm mających na celu ochronę pracowników przed molestowaniem w miejscu pracy lub w związu z praca, nowelą z 14 listopada 2003 r. dodał do przykładowego katalogu podstawowych obowiązków pracodawcy $\mathrm{z}$ art. 94 k.p. obowiazek przeciwdziałania dyskryminacji w zatrudnieniu, w szczególności ze względu na płeć, wiek, niepełnosprawność, rasę, religię, narodowość, przekonania polityczne, przynależność związkową, pochodzenie etniczne, wyznanie, orientację seksualną, a także ze względu na zatrudnienie na czas określony lub nieokreślony albo w pełnym lub niepełnym wymiarze czasu pracy ${ }^{32}$. Z punktu widzenia implementacji wspólnotowych norm antydyskryminacyjnych istotne są również zmiany w rozdziale IIa w dziale pierwszym kodeksu pracy.

Polski ustawodawca poza tym, że zdefiniował pojęcie dyskryminacji bezpośredniej i uszczegółowił pojęcie dyskryminacji pośredniej, sformułowat definicje ,molestowania" i "molestowania seksualnego". I tak, zgodnie $\mathrm{z}$ art. $18^{3 \mathrm{a}} \S 5$ pkt 2 k.p., molestowanie to zachowanie, którego celem lub skutkiem jest naruszenie godności albo poniżenie lub upokorzenie pracownika. $Z$ kolei molestowaniem seksualnym jest każde nieakceptowane zachowanie o charakterze seksualnym lub odnoszące się do płci pracownika. Cel lub skutek tego zachowania jest taki sam jak w przypadku molestowania: naruszenie godności albo poniżenie lub upokorzenie pracownika. Na molestowanie seksualne mogą składać się elementy fizyczne, werbalne lub pozawerbalne. Należy podkreślić, że polski ustawodawca expressis verbis uznaje molestowanie seksualne za przejaw dyskryminacji ze względu na płeć ${ }^{33}$.

Porównując definicje „molestowania” i „molestowania seksualnego”, wprowadzone do polskiego kodeksu pracy, z definicjami zawartymi w dyrektywach, I. Boruta wskazuje, że polski ustawodawca, w odróżnieniu od unijnego prawodawcy, nie wiąże molestowania $z$ niepożądanym zachowaniem na tle płci, rasy, pochodzenia, etnicznego, religii, przekonań, wieku, niepełnosprawności czy orientacji seksualnej. Wprowadzona do kodeksu pracy definicja „molestowania" utożsamia to zachowanie z naruszeniem godności, a co za tym idzie polski ustawodawca chroni godność pracownika, wykorzystując normy antydyskryminacyjne. I. Boruta podkreśla poza tym, że w kodeksie pracy nie odróżnia się „molestowania ze względu na płeć" od „molestowania seksualnego" ${ }^{34}$. Takie rozróżnienie uwidacznia się na gruncie wspólnotowych norm antydyskryminacyjnych.

32 Por. art. 94 pkt 2b k.p. dodany przez art. 1 pkt 27 ustawy z 14 XI 2003 r. o zmianie ustawy - Kodeks pracy oraz o zmianie niektórych innych ustaw, Dz.U. Nr 213, poz. 2081.

${ }^{33}$ Por. art. $18^{3 \mathrm{a}} \S 6$ k.p.

34 I. Boruta, Zakaz dyskryminacji w zatrudnieniu - nowa regulacja, PiZS 2004, nr 2, S. 5. 


\section{Obowiązki pracodawcy \\ w zakresie przeciwdzialania mobbingowi}

Mobbing $^{35}$ stał się przedmiotem regulacji prawnych w wielu krajach europejskich, uregulowań w tym zakresie można doszukać się także w europejskim prawie pracy.

W art. 26 ust. 2 Zrewidowanej Europejskiej Karty Społecznej mowa jest o potrzebie przeciwdziałania czynom wyraźnie nieprzyjaznym i obraźliwym, skierowanym przeciw poszczególnym pracownikom w miejscu pracy lub $w$ związku $z$ pracą. Wydaje się, że $w$ cytowanym przepisie wskazano na istotę zachowań, które moga być uznane za przejaw mobbingu w środowisku pracy, chociaż nie posłużono się terminem „mobbing” w odniesieniu do tych zachowań.

Problem mobbingu w miejscu pracy lub w związku z pracą został dostrzeżony nie tylko przez Radę Europy. 20 września 2001 r. Parlament Europejski przyjał rezolucję w sprawie nękania w miejscu pracy. Problem nękania pojawia się również w Komunikacie Komisji Europejskiej z marca 2002 r. dotyczącym strategii w zakresie zdrowia i bezpieczeństwa w miejscu pracy w latach 2002-2006. W komunikacie wskazano, że nękanie i przemoc $w$ środowisku pracy stanowią zagrożenie dla zdrowia pracowników, a przeciwdziałanie tym zjawiskom wymaga nowych regulacji zarówno w prawie wspólnotowym, jak i w ustawodawstwach krajowych poszczególnych krajów członkowskich Unii Europejskiej ${ }^{36}$.

Mobbing stał się już przedmiotem regulacji prawnych w wielu krajach członkowskich Unii Europejskiej. Szwecja jako pierwsza całościowo uregulowała problem mobbingu $\mathrm{w}$ miejscu pracy lub $\mathrm{w}$ związku $z$ pracą ${ }^{37}$. Przepisy antymobbingowe zostały wprowadzone również do ustawodawstwa Francji, Belgii oraz Wielkiej Brytanii.

${ }^{35}$ Mobbing to szczególny rodzaj konfliktu w środowisku pracy. W zależności od tego, kto jest dręczycielem (mobberem), rozróżnia się mobbing: a) pionowy - mobberem jest pracodawca albo bezpośredni przełożony, a ofiarą pracownik, b) poziomy (horyzontalny lub grupowy) - mobberem jest współpracownik lub grupa współpracowników, c) wstępujący mobberem jest pracownik, a ofiarą bezpośredni przełożony tego pracownika. Por. A. Bechowska-Gebhardt, T. Stalewski, Mobbing - patologia zarządzania personelem, Warszawa 2004, s. 10.

${ }^{36}$ M. Jurkiewicz, Nowelizacja kodeksu pracy. Mobbing zakazany. W Unii Europejskiej od lat, $u$ nas od przyszłego roku, Gazeta Prawna z 9 XII 2003 r., nr 239 (1095).

${ }^{37}$ Dnia 31 marca 1994 r. weszło w życie rozporządzenie w sprawie środków przeciwdziałania zjawisku gnębienia w miejscu pracy (Order on Victimization at Work). W rozporządzeniu tym zdefiniowano pojęcie „gnębienia” oraz określono obowiązki pracodawcy w zakresie przeciwdziałania zjawisku gnębienia w miejscu pracy. Por. J. Marciniak, Przeciwdziatanie dyskryminacji w zatrudnieniu. Jak zwalczać mobbing i inne formy dyskryminacji w zatrudnieniu, Ostrołęka 2004, s. 62-63. 
W Niemczech nie ma jeszcze specjalnej ustawy antymobbingowej. W literaturze przedmiotu wskazuje się jednak, że instrumentów prawnych chroniących pracowników przed mobbingiem można doszukać się w niemieckiej ustawie zasadniczej oraz w niemieckiej ustawie o ustroju pracy (Bertiebsverfassungsgesetz). Poza tym podkreśla się, że z ogólnego obowiąku pieczy nad pracownikiem (Füsorgenpflicht), nałożonego na pracodawcę, wynika również obowiązek przeciwdziałania mobbingowi. Pracodawca narusza obowiązek pieczy nad pracownikiem, jeżeli toleruje mobbing w miejscu pracy i nie udziela pomocy jego ofiarom ${ }^{38}$.

Polski ustawodawca przepisy antymobbingowe wprowadził do kodeksu pracy. Nowela z 14 listopada 2003 r. dodano art. $94^{3}$ k.p. ${ }^{39}$ Zgodnie z $§ 2$ tego artykułu, mobbing to działania lub zachowania dotyczące pracownika lub skierowane przeciwko pracownikowi, polegające na uporczywym i długotrwałym nękaniu lub zastraszaniu pracownika ${ }^{40}$, wywołujące u niego zaniżoną ocenę przydatności zawodowej, powodujące lub mające na celu poniżenie lub ośmieszenie pracownika, izolowanie go lub wyeliminowanie z zespołu współpracowników. Pracodawca jest obowiązany przeciwdziałać takim działaniom lub zachowaniom (czyli mobbingowi) ${ }^{41}$. Pracodawca nie tylko nie może podejmować działań mobbingowych, lecz także musi przeciwdziałać podejmowaniu takich działań przez pracowników w stosunku do innych pracowników ${ }^{42}$.

Wprowadzenie do polskiego kodeksu pracy przepisów antymobbingowych jest istotne z punktu widzenia ochrony dóbr osobistych pracownika. W związku $\mathrm{z}$ wejściem $\mathrm{w}$ życie tych przepisów w środkach masowego przekazu została podjęta dyskusja, której przedmiotem był problem mobbingu w środowisku pracy. Wydaje się, że mobbing w miejscu pracy lub w związku z pracą przestaje być w Polsce zjawiskiem skrywanym. Podejmowane są próby wyeliminowania tego zjawiska oraz pomocy ofiarom mobbingu. Instrumentami prawnymi mającymi przeciwdziałać występowaniu tego zjawi-

${ }^{38}$ H. Szewczyk, Molestowanie seksualne $i$ mobbing $w$ miejscu pracy lub $w$ zwiqzku z praca, PiZS 2002, nr 6, s. 10.

${ }^{39}$ Por. art. 1 pkt 30 ustawy z 14 XI 2003 r. o zmianie ustawy - Kodeks pracy oraz o zmianie niektórych innych ustaw, Dz.U. Nr 213, poz. 2081.

${ }^{40}$ Należy tu podkreślić, że aby pewne działania lub zachowania mogły być uznane za mobbing na gruncie przepisów polskiego prawa pracy, muszą prowadzić do uporczywego i długotrwałego nękania lub zastraszania pracownika. Działania (zachowania) mobbingowe to działania (zachowania) ustawiczne, powtarzające się przez dłuższy okres. Za mobbing nie może być zatem uznane jednorazowe działanie lub zachowanie.

${ }^{41}$ Por. art. $94^{3} \S 1$ k.p.

${ }^{42}$ Por. m.in.: J. Piątkowski, Prawo pracy i zabezpieczenia spotecznego. Suplement (do: K. Kolasiński, Prawo pracy i zabezpieczenia spotecznego, Toruń 2003), Torun 2004, s. 47; W. Cajsel, Kodeks pracy. Komentarz do nowelizacji, Warszawa 2004, s. 159. 
ska są przepisy antymobbingowe, które zostały wprowadzone do kodeksu pracy. Same rozwiązania prawne jednak nie wystarczą, aby wyeliminować zjawisko mobbingu ze środowisk pracy. Nie sposób nie zauważyć, że istotną rolę w tym zakresie odgrywa również działalność stowarzyszeń prowadzących poradnictwo prawne i psychologiczne dla osób, które stały się ofiarami mobbingu.

\section{Obowiązki pracodawcy jako administratora danych a ochrona danych osobowych pracownika}

W dokumentach Rady Europy oraz w prawie wspólnotowym znalazły się uregulowania, określające zasady przetwarzania danych osobowych oraz mające zapewnić tzw. minimum ochrony interesów osób, których dane są lub mogą być przetwarzane w zbiorach danych. Należy zauważyć, że zarówno w dokumentach Rady Europy ${ }^{43}$, jak i w prawie wspólnotowym ${ }^{44}$ znajdują się uregulowania odnośnie do przetwarzania danych osobowych w związku $\mathrm{z}$ zatrudnieniem. Uregulowania te, statuując uprawnienia pracodawcy $\mathrm{w}$ zakresie przetwarzania danych osobowych pracownika, nakładają na niego równocześnie obowiązki w zakresie ochrony interesów tego pracownika. Polski ustawodawca również nakłada na pracodawcę obowiązki w zakresie ochrony interesów pracownika, którego dane osobowe są przetwarzane w związku z zatrudnieniem. Obowiązi te wynikają przede wszystkim $\mathrm{z}$ art. $22^{1}$ k.p. oraz z ustawy z 29 sierpnia 1997 r. o ochronie danych osobowych ${ }^{45}$.

${ }^{43}$ Aby chronić interesy pracowników, których dane osobowe są przetwarzane w związku $z$ zatrudnieniem, $w$ ramach Rady Europy opracowano wiele rezolucji oraz rekomendacji, które są uszczegółowieniem przepisów Konwencji 108 Rady Europy z 28 I 1981 r. dotyczącej ochrony osób w związku $z$ automatycznym przetwarzaniem danych osobowych. Wśród tych rezolucji i rekomendacji szczególne znaczenie należy przypisać Rezolucji 3 z 1995 r. dotyczącej karty oceny zawodowej osób niepełnosprawnych oraz dwom rekomendacjom: w sprawie ochrony danych osobowych przetwarzanych $w$ związku z zatrudnieniem i rekomendacji dotyczącej ochrony danych osobowych wykorzystywanych $w$ związku $z$ ubezpieczeniem społecznym pracowników.

${ }^{44}$ W Dyrektywie Parlamentu Europejskiego i Rady Unii Europejskiej 95/46/WE z 24 X $1995 \mathrm{r}$. w sprawie ochrony osób fizycznych w zakresie przetwarzania danych osobowych oraz swobodnego przepływu (Dz.Urz. L 281/31) tych danych określono kryteria legalności przetwarzania danych osobowych (art. 7). W dyrektywie tej sformułowano zakaz przetwarzania tzw. danych wrażliwych. Od tego zakazu przewidziano jednak wyjątki. Tzw. dane wrażliwe mogą być przetwarzane wtedy, gdy jest to konieczne do wypełniania obowiązków i szczególnych uprawnień administratora danych w dziedzinie prawa pracy. Muszą być spełnione jeszcze dwa warunki, a mianowicie: przetwarzanie tych danych w związku $z$ zatrudnieniem jest dozwolone przez prawo krajowe, które musi przewidywać odpowiednie zabezpieczenia (art. 8).

${ }^{45}$ Dz.U. z 2002 r., Nr 153, poz. 1271 ze zm. 
Pracodawca jest obowiązany przetwarzać dane osobowe, mając na uwadze tzw. przesłanki legalizujące przetwarzane danych osobowych (art. 23). Podstawowe obowiązki pracodawcy jako administratora danych osobowych zostały określone w art. 26 ust. 1 ustawy. Zgodnie $\mathrm{z}$ tym przepisem administrator danych powinien dołożyć szczególnej staranności w celu ochrony interesów osób, których dane dotycza, w tym przypadku osób ubiegających się o zatrudnienie oraz osób zatrudnionych. Należy tu podkreślić, że ustawa o ochronie danych osobowych statuuje ochronę interesów nie tylko pracowników, ale także osób świadczących pracę na innej podstawie niż stosunek pracy. Mając na uwadze ochronę interesów tych osób, administrator danych w szczególności jest obowiązany zapewnić, aby dane były: przetwarzane zgodnie $\mathrm{z}$ prawem, zbierane dla oznaczonych, zgodnych z prawem celów i niepoddawane dalszemu przetwarzaniu niezgodnemu $\mathrm{z}$ tymi celami, merytorycznie poprawne i adekwatne w stosunku do celów, w jakich są przetwarzane, a poza tym przechowywane w postaci umożliwiającej identyfikację osób, których dotyczą, nie dłużej niż jest to niezbędne do osiagnięcia celu przetwarzania.

W literaturze przedmiotu podkreśla się, że ustawa o ochronie danych osobowych nie normuje wyczerpująco problematyki przetwarzania przez pracodawcę danych osobowych innych niż tzw. dane wrażliwe ${ }^{46}$. Zgodnie

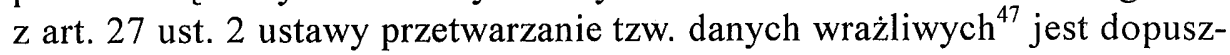
czalne, jeżeli jest ono niezbędne do wykonywania zadań administratora danych, odnoszących się do zatrudniania pracowników i innych osób, a zakres przetwarzania danych jest określony w ustawie. Należy przyjąć, że sformułowanie „niezbędne do wykonywania zadań” jest zwrotem niedookreślonym, który wskazuje na dalej idące ograniczenia przetwarzania danych osobowych niż wynikające $\mathrm{z}$ zasady adekwatności ${ }^{48}$.

Zakres danych osobowych, których może żądać pracodawca od osoby ubiegającej się o zatrudnienie oraz od pracownika, określony został $\mathrm{w}$ art. $22^{1}$ k.p. Zgodnie z $\S 4$ tego artykułu, pracodawca może żądać podania innych danych osobowych, jeżeli obowiązek podania tych danych wynika z odrębnych przepisów. Jako przykład można podać art. 6 ust. 1 pkt 10 ustawy z 24 maja 2000 r. o Krajowym Rejestrze Karnym ${ }^{49}$. Powołując się na ten

46 J. Barta, R. Markiewicz, Ochrona danych osobowych. Komentarz, Kraków 2002, s. 433.

47 Tzw. dane wrażliwe to: dane ujawniające pochodzenie rasowe lub etniczne, poglądy polityczne, przekonania religijne lub filozoficzne, przynależność wyznaniowa, partyjną lub związkową jak również dane o stanie zdrowia, kodzie genetycznym, nałogach lub życiu seksualnym oraz dane dotyczące skazań, orzeczeń o ukaraniu i mandatów karnych, a także innych orzeczeń wydanych w postępowaniu sądowym lub administracyjnym (art. 27 ust. 1 ustawy o ochronie danych osobowych).

48 A. Drozd, Ustawa o ochronie danych osobowych. Komentarz. Wzory pism i przepisy, Warszawa 2004, s. 171.

49 Dz.U. Nr 50, poz. 580 ze zm. 
artykuł, pracodawca ma prawo do uzyskania informacji o osobach, których dane zostały zgromadzone w Krajowym Rejestrze Karnym, jeżeli informacje te dotyczą pracownika, co do którego z przepisów ustawy wynika wymóg niekaralności, korzystania z pełni praw publicznych, a także ustalenia uprawnienia do zajmowania określonego stanowiska, wykonywania określonego zawodu lub prowadzenia określonej działalności gospodarczej ${ }^{50}$.

Należy podkreślić, że $w$ art. $22^{1}$ k.p. określa się jedynie zakres danych osobowych, których może żądać pracodawca. Nie wprowadza się natomiast ograniczeń w zakresie udostępniania pracodawcy danych osobowych z inicjatywy osoby ubiegającej się o zatrudnienie oraz pracownika. W związku $\mathrm{z}$ tym istnieje niebezpieczeństwo, że pracodawca będzie żądał przedstawienia innych danych osobowych niż te wymienione w art. $22^{1}$ k.p., wskazując, że kandydat na pracownika czy też pracownik uczynił to $z$ własnej inicjatywy ${ }^{51}$.

W literaturze przedmiotu podkreśla się, że przetwarzanie danych osobowych w związku z zatrudnieniem nie może prowadzić do naruszenia dóbr osobistych pracownika, a także stanowić podstawy stosowania praktyk dyskryminacyjnych. Wskazuje się, że domaganie się przez pracodawcę od pracownika danych osobowych innych niż to przewidują przepisy, a w przypadku kandydata na pracownika uzależnianie rozpatrzenia podania o zatrudnienie od przedstawienia tych danych, stanowi praktykę jawnie dyskryminującą oraz godzącą w godność oraz inne dobra osobiste ${ }^{52}$.

Ustawa o ochronie danych osobowych nakłada na pracodawce jako administratora danych również obowiązki o charakterze technicznym i organizacyjnym, a także obowiązki w zakresie prowadzenia dokumentacji osobowej i organizacyjnej z zakresu ochrony danych osobowych (art. 36) ${ }^{53}$. Szczegółowe uregulowania co do zakresu tych obowiązków znajdują się w rozporządzeniu Ministra Spraw Wewnętrznych i Administracji z 29 kwietnia 2004 r. w sprawie dokumentacji przetwarzania danych osobowych oraz warunków technicznych i organizacyjnych, jakim powinny odpowiadać urządzenia i systemy informatyczne służące do przetwarzania danych osobowych ${ }^{54}$.

${ }^{50}$ Taki wymóg wynika m.in. z: art. 4 ustawy z 18 XII 1998 r. o służbie cywilnej, Dz.U. z 1999 r., Nr 49, poz. 483 ze zm.; art. 5 ustawy z 6 IX 2001 r. o transporcie drogowym Dz.U. Nr 125, poz. 1371 ze zm.; art. 10 ust. 5 pkt 2-4 ustawy z 26 I 1982 r. Karta Nauczyciela, Dz.U. z 2003 r., Nr 118, poz. 1112 ze zm.

51 A. Drozd, Ochrona danych osobowych (kandydata na) pracownika po nowelizacji kodeksu pracy, Praca i Zabezpieczenie Społeczne 2004, nr 1, s. 26.

52 J. Barta, R. Markiewicz, op.cit., s. 367.

53 Szerzej na ten temat: J. Borowicz, Obowiazek prowadzenia przez pracodawce dokumentacji osobowej $i$ organizacyjnej z zakresu ochrony danych osobowych, PiZS 2001, nr 3, s. 7 i n.

${ }^{54}$ Dz.U. Nr 100, poz. 1024. 


\section{Skutki prawne naruszenia dóbr osobistych pracownika}

\section{Odpowiedzialność pracodawcy za naruszenie generalnego obowiązku szanowania godności i innych dóbr osobistych pracownika}

Pracownik, którego dobra osobiste zostały bezprawnie naruszone lub zagrożone, korzysta $\mathrm{z}$ cywilnoprawnych środków służących ochronie dóbr osobistych, przewidzianych w art. 24 k.c. ${ }^{55}$ Przysługują mu środki ochronne w postaci: powództwa o ustalenie (art. 189 k.p.c.), roszczeń niemajątkowych (o zaniechanie działań, które zagrażają dobrom osobistym; o usunięcie skutków naruszenia dobra osobistego) oraz roszczeń majątkowych (o zadośćuczynienie lub o zapłatę sumy pieniężnej na wskazany cel społeczny) ${ }^{56}$. Ponadto, jeżeli wskutek naruszenia dobra osobistego została wyrządzona szkoda majątkowa, może żądać jej naprawienia na zasadach ogólnych ${ }^{57}$. Należy tu podkreślić, że środki ochrony przewidziane w art. 24 k.c. to minimalny standard ochronny przysługujący każdej osobie fizycznej, której dobra osobiste zostały bezprawnie naruszone (zagrożone) $)^{58}$.

Pracownik, którego godność lub inne dobra osobiste zostały naruszone, może skorzystać ze środków ochrony przewidzianych $\mathrm{w}$ przepisach prawa pracy. W literaturze przedmiotu podnosi się, że ciężkie naruszenie przez pracodawcę obowiazzku szanowania godności lub innego dobra osobistego pracownika może być podstawa do rozwiązania przez pracownika umowy o pracę bez wypowiedzenia w trybie art. $55 \S 1^{1}$ k.p. i roszczenia o odszko-

${ }^{55} \mathrm{~W}$ doktrynie prawa pracy dyskutowany jest problem, czy w przypadku naruszenia (zagrożenia) dóbr osobistych pracownika art. 23 i 24 k.c. znajdują zastosowanie tylko wtedy, gdy zostały spełnione przesłanki $z$ art. $300 \mathrm{k} . p .$, czy też $\mathrm{z}$ pominięciem tego przepisu. Zdania, że przepisy kodeksu cywilnego (art. 23 i 24) w zakresie ochrony dóbr osobistych pracownika stosuje się odpowiednio, są m.in.: M. Dyczkowski, op.cit., s. 10; Z. Salwa (Kodeks pracy po nowelizacji. Komentarz, Bydgoszcz 1996, s. 33; idem, Podstawy prawa pracy, Warszawa 2001, s. 31); K. Raczka (por. Kodeks pracy po nowelizacji z komentarzem, Warszawa 1996, s. 9). Z kolei zdania, że przepisy te stosuje się z pominięciem art. 300 k.p., są m.in.: T. Zieliński (por. Komentarz do art. $11^{1}$ k.p., [w:] Kodeks pracy. Komentarz, pod red. T. Zielińskiego, Warszawa 2000, s. 157); T. Wyka (por. Ochrona zdrowia i życia pracownika jako element treści stosunku pracy, Warszawa 2003, s. 140); I. Boruta (por. Godność czlowieka - kategoriq prawa pracy, PiZS 2001, nr 8, s. 4); A. Stefaniak (por. Kodeks pracy, Warszawa 1998, s. 23). Uzasadniony wydaje się pogląd, że w przypadku naruszenia (zagrożenia) dóbr osobistych pracownika stosuje się art. 23 i 24 k.c. z pominięciem art. 300 k.p.

56 Por. art. $24 \S 1$ k.p.

57 Por. art. $24 \S 2$ k.p. Naprawienie szkody majątkowej „na zasadach ogólnych”, czyli na zasadach określonych w księdze trzeciej kodeksu cywilnego (Zobowiqzania): art. 361-363, 415 i n. k.c.

${ }^{58}$ Z. Radwański, Prawo cywilne..., s. 174. 
dowanie $^{59}$. Należy zauważyć, że $\mathrm{z}$ ciężkim naruszeniem tego obowiązku możemy mieć do czynienia zarówno wtedy, gdy pracodawca naruszy określone dobro osobiste pracownika, jak i wówczas, gdy pracodawca nie stworzył warunków sprzyjających szanowaniu dóbr osobistych pracownika przez osoby trzecie.

\section{Odpowiedzialność pracodawcy za naruszenie szczegółowych obowiązków w zakresie szanowania dóbr osobistych pracownika}

\section{Odpowiedzialność pracodawcy za molestowanie seksualne}

Pracodawca ponosi odpowiedzialność zarówno za szantaż seksualny, jak i molestowanie seksualne, które polega na stworzeniu nieprzyjaznych (wrogich) warunków pracy. Może on ponosić odpowiedzialność na podstawie przepisów prawa pracy, prawa cywilnego oraz prawa karnego ${ }^{60}$.

Koncentrując się na odpowiedzialności pracodawcy na podstawie przepisów prawa pracy, należy podkreślić, że w sytuacji gdy w zakładzie pracy występuje zjawisko molestowania seksualnego, pracodawca jest odpowiedzialny za naruszenie zasady równego traktowania w zatrudnieniu, a także nieposzanowanie godności i innych dóbr osobistych pracownika. $Z$ definicji molestowania seksualnego, sformułowanej w art. $18^{3 \mathrm{a}} \S 6$ k.p., wyni$\mathrm{ka}$, że prowadzi ono przede wszystkim do naruszenia godności pracownika. W związku z molestowaniem seksualnym może dojść także do naruszenia innych dóbr osobistych pracownika, m.in. jego prawa do prywatności, integralności seksualnej, a także zdrowia. Występowanie zjawiska molestowania seksualnego w zakładzie pracy wskazuje również na to, że pracodawca nie uczynił zadość obowiązkowi zapewnienia bezpiecznych i higienicznych warunków pracy ${ }^{61}$ oraz obowiązkowi wpływania na kształtowanie w zakładzie pracy zasad współżycia społecznego (art. 94 pkt 10 k.p.). Należy tu podkreślić, że obowiązek równego traktowania w zatrudnieniu, obowiązek

${ }^{59}$ Por. L. Florek, T. Zieliński, Prawo pracy, Warszawa 2004, s. 14.

${ }^{60} \mathrm{~W}$ niniejszym opracowaniu zostanie omówiona odpowiedzialność pracodawcy na podstawie przepisów prawa pracy. Przedstawienie problemów związanych z cywilnoprawną oraz karną odpowiedzialnością pracodawcy za molestowanie seksualne w miejscu pracy lub w związku z pracą przekracza ramy niniejszego opracowania.

${ }^{61}$ SN wyraził pogląd, że obowiązek pracodawcy zapewnienia bezpiecznych i higienicznych warunków pracy polega na stworzeniu bezpiecznego środowiska pracy. Pracodawca dopuszcza się naruszenia tego obowiązku, jeżeli, wiedząc o stanie zagrożenia zdrowia pracownika, wywołanego bezprawnym zachowaniem innej osoby, nie podejmuje żadnych działań w celu usunięcia takiego stanu rzeczy. Por. wyrok SN z 5 III 1970 r., I PR2/70, opubl.: OSNC 1970, nr 11, poz. 205. 
szanowania godności i innych dóbr osobistych pracownika oraz obowiązek wpływania na kształtowanie w zakładzie pracy zasad współżycia społecznego to podstawowe obowiazki pracodawcy wobec pracownika. Jest to istotne $\mathrm{z}$ punktu widzenia dopuszczalności niezwłocznego rozwiązania stosunku pracy przez pracownika. Jeżeli pracownik-ofiara molestowania seksualnego wykaże, że pracodawca dopuścił się „ciężkiego naruszenia"62 powyższych obowiązków, wówczas ma prawo do rozwiązania umowy o pracę w trybie art. $55 \S 1^{1}$ k.p. Pracownikowi, który rozwiązał umowę o pracę bez wypowiedzenia, przysługuje odszkodowanie za okres wypowiedzenia, a jeżeli umowa została zawarta na czas określony lub na czas wykonania określonej pracy - w wysokości wynagrodzenia za okres dwóch tygodni.

W związku z tym, że molestowanie seksualne jest przejawem dyskryminacji ze względu na płeć, pracownik-ofiara molestowania seksualnego (jako osoba, wobec której pracodawca naruszył zasadę równego traktowania w zatrudnieniu) ma prawo do odszkodowania w wysokości nie niższej niż minimalne wynagrodzenie za pracę ${ }^{63}$. Pracownik musi jedynie przedstawić uprawdopodobniony zarzut, że stał się ofiarą molestowania seksualnego. Jeżeli pracodawca chce się eskulpować od odpowiedzialności odszkodowawczej, musi udowodnić, że nie doszło do naruszenia zasady równego traktowania w zatrudnieniu ${ }^{64}$, a zatem że nie mamy do czynienia z dyskryminacją ze względu na płeć, której przejawem jest molestowanie seksualne w rozumieniu art. $18^{3 \mathrm{a}} \S 6 \mathrm{k} . \mathrm{p}$.

\section{Odpowiedzialność pracodawcy za mobbing}

$\mathrm{Na}$ gruncie polskiego prawa pracy podstawowe znaczenie dla odpowiedzialności pracodawcy za mobbing ${ }^{65}$ ma art. $94^{3}$ k.p. Zgodnie z $\S 3$. tego artykułu pracownik, u którego mobbing wywołał rozstrój zdrowia, może dochodzić od pracodawcy zadośćuczynienia pieniężnego za doznaną

62 Jeżeli pracodawcy można przypisać winę lub rażące niedbalstwo, wówczas będziemy mieli do czynienia $\mathrm{z}$ „ciężkim naruszeniem” podstawowych obowiązków pracodawcy wobec pracownika. Por. m.in. wyrok SN z 4 IV 2000 r., I PKN 516/99, opubl.: OSNAPiUS 2001, poz. 516.

${ }^{63}$ Por. art. $18^{3 \mathrm{~d}}$ k.p.

${ }^{64}$ Art. $18^{3 b} \S 1$ k.p. wprowadza przerzucenie ciężaru dowodu na pracodawcę $w$ razie przedstawienia przez pracownika uprawdopodobnionego zarzutu naruszenia zasady równego traktowania w zatrudnieniu. Należy tu zauważyć, że rozwiązanie przyjęte $w$ art. $18^{3 \mathrm{~b}} \S 1$ k.p. koresponduje z art. 4 dyrektywy 97/80/WE z 15 XII 1997 r. dotyczącej ciężaru dowodu w przypadku dyskryminacji ze względu na płeć.

${ }_{65}$ Rozważania ograniczą się do odpowiedzialności pracodawcy na podstawie przepisów prawa pracy, podobnie jak w przypadku odpowiedzialności za molestowanie seksualne w miejscu pracy lub w związku z praca. 
krzywde $^{66}$. Mając na uwadze brzmienie tego przepisu, należy stwierdzić, że pracownik-ofiara mobbingu może wystąpić z roszczeniem o zadośćuczynienie tylko wówczas, gdy praktyki mobbingowe spowodowały u niego rozstrój zdrowia.

Działania mobbingowe, bez względu na to czy są podejmowane przez pracodawcę, czy też przez pracowników, stanowią naruszenie podstawowych obowiązków pracodawcy wobec pracownika, przede wszystkim obowiązku zapewnienia pracownikowi bezpiecznych i higienicznych warunków pracy oraz obowiązku szanowania godności i innych dóbr osobistych pracownika. W związku z tym, podobnie jak w przypadku molestowania seksualnego, istnieja podstawy do rozwiązania umowy o prace w trybie art. 55 $\S 1^{1}$ k.p., jeżeli pracownik wykaże, że mamy do czynienia $z$ „ciężkim naruszeniem".

Zgodnie z art. $94^{3} \S 4$ k.p. pracownik, który wskutek mobbingu rozwiązał umowę o pracę, ma prawo dochodzić od pracodawcy odszkodowania w wysokości nie niższej niż minimalne wynagrodzenie za pracę. W literaturze przedmiotu podkreśla się, że to odszkodowanie jest skonstruowane w sposób podobny do odszkodowania za naruszenie zasady równego traktowania w zatrudnieniu. Przepisy kodeksu pracy nie przewidują jednak ułatwień dowodowych dla pracowników zgłaszających roszczenia odszkodowawcze $z$ tytułu stosowania wobec nich działań mobbingowych ${ }^{67}$. Muszą oni udowodnić, zgodnie $\mathrm{z}$ ogólną regułą dowodową wyrażoną w art. 6 k.c., że stali się ofiarami mobbingu w rozumieniu art. $94^{3} \S 2$ k.p.

Pracownik-ofiara mobbingu może skorzystać także z cywilnoprawnych instrumentów chroniących dobra osobiste. Pracownikowi będą przysługiwały roszczenia majątkowe i niemajątkowe, określone w art. 24 oraz 445-448 k.c. ${ }^{68}$ Należy ponadto zauważyć, że działania mobbingowe wywołują nie tylko skutki określone w przepisach prawa pracy oraz prawa cywilnego, ale bardzo często wyczerpują one również znamiona przestępstw (m.in. przeciwko zdrowiu i życiu).

${ }^{66} \mathrm{~W}$ art. $94^{3} \S 3$ k.p. ustawodawca posłużył się pojęciami: „rozstrój zdrowia”, „krzywda" i „zadośćuczynienie pieniężne". Nie sposób nie zauważyć, że do kodeksu pracy przeniesiono siatkę pojęciową charakterystyczną dla przepisów prawa cywilnego, statuujących ochronę dóbr osobistych. Przy wykładni art. $94^{3} \S 3$ k.p. mogą być zatem przydatne poglądy ustalone w teorii prawa cywilnego.

${ }^{67}$ W. Cajsel, op.cit., s. 161.

${ }^{68} \mathrm{~W}$ literaturze przedmiotu podnosi się, że nie ma potrzeby tworzenia dwóch systemów ochrony dóbr osobistych, $\mathrm{z}$ których pierwszy będzie zawarty w kodeksie cywilnym, a drugi w kodeksie pracy. Wskazuje się ponadto, że przepisy antymobbingowe w kodeksie pracy obniżają standardy w zakresie ochrony dóbr osobistych. Por. G. Jędrejek, Cywilnoprawna odpowiedzialność za stosowanie mobbingu, Warszawa 2004, s. 259 i n. 


\section{Odpowiedzialność pracodawcy za niezgodne z prawem przetwarzanie danych osobowych pracownika}

Konwencja 108 Rady Europy z 1981 r. dotycząca ochrony osób fizycznych $w$ związku $z$ automatycznym przetwarzaniem danych osobowych posługuje się zwrotem „zarządca kartoteki”. Zgodnie z art. 2 pkt 4 Konwencji zarządcą kartoteki może być „osoba fizyczna lub prawna, władza publiczna lub inne ciało upoważnione na podstawie prawa wewnętrznego". Zarządcą kartoteki w rozumieniu Konwencji może być także pracodawca. Należy podkreślić, że w Konwencji nie mówi się wprost o odpowiedzialności zarządcy kartoteki za niezgodne $\mathrm{z}$ prawem przetwarzanie danych. Chociaż, zgodnie $z$ art. 10 Konwencji, w prawie wewnętrznym powinny być przewidziane sankcje karne oraz odszkodowawcze za naruszenie przepisów z zakresu ochrony danych osobowych.

W Dyrektywie Parlamentu Europejskiego i Rady Unii Europejskiej z 1995 r. w sprawie ochrony osób fizycznych w zakresie przetwarzania danych osobowych oraz swobodnego przepływu tych danych zwraca się szczególną uwagę na odpowiedzialność odszkodowawczą administratora danych, który wskutek niezgodnego z przepisami krajowymi przetwarzania danych osobowych wyrządził szkodę osobie, której dane dotycza. Zgodnie z art. 22 tejże dyrektywy, osoba, której prawa przewidziane przez przepisy prawa krajowego z zakresu ochrony danych osobowych zostały naruszone, może wystapić na drogę sądową przeciwko administratorowi danych, niezależnie od środków administracyjnoprawnych. Administrator danych może ekskulpować się od odpowiedzialności odszkodowawczej, jeżeli udowodni, że nie jest odpowiedzialny za zdarzenie, które spowodowało szkodę (art. 23 ust. 2).

Należy podkreślić, że w polskiej ustawie o ochronie danych osobowych przewidziano jedynie sankcje karne za niezgodne $\mathrm{z}$ prawem przetwarzanie danych osobowych, nie ma natomiast przepisów regulujących problem odpowiedzialności odszkodowawczej administratora danych. W literaturze przedmiotu podnosi się, że dyskusyjne jest, czy w prawie polskim istnieje, niezależne od środków administracyjnoprawnych, uprawnienie do domagania się na drodze sądowej ochrony praw przewidzianych w ustawie o ochronie danych osobowych. Poszukując normatywnej podstawy tego uprawnienia, wskazuje się na przepisy kodeksu cywilnego, statuujące ochronę dóbr osobistych. Nie wszystkie jednak naruszenia praw jednostki, przewidzianych w ustawie o ochronie danych osobowych, stanowią bezprawne naruszenie dobra osobistego w rozumieniu art. 23 i 24 k.c. ${ }^{69}$

W kodeksie pracy nie przewidziano sankcji $z$ tytułu naruszenia dyspozycji art. $22^{1}$, który określa, podania jakich danych osobowych może doma-

69 J. Barta, R. Markiewicz, op.cit., s. 145. 
gać się pracodawca od pracownika oraz osoby ubiegającej się o zatrudnienie. W stosunku do pracodawcy, który przetwarza dane osobowe niezgodnie $\mathrm{z}$ prawem (m.in. naruszając art. $22^{1}$ k.p.), znajdują zastosowanie sankcje karne, przewidziane w ustawie o ochronie danych osobowych. Kandydat na pracownika, a także pracownik, w stosunku do którego pracodawca naruszył zasadę równego traktowania w zatrudnieniu, żądając udostępnienia innych danych osobowych w art. $22^{1} \mathrm{k}$.p. oraz w odrębnych przepisach, ma prawo do odszkodowania, na zasadach określonych w rozdziale IIa (Równe traktowanie w zatrudnieniu) w dziale pierwszym kodeksu pracy. Poza tym, jeżeli w związku z przetwarzaniem danych osobowych przez pracodawcę doszło do bezprawnego naruszenia dóbr osobistych (kandydata na) pracownika, może on wystąpić z roszczeniami przewidzianymi w art. 24 k.c.

\section{Ochrona dóbr osobistych pracownika w Polsce a europejskie standardy - wnioski}

1. Problem ochrony godności oraz innych dóbr osobistych pracownika jest zagadnieniem złożonym, a zarazem interdyscyplinarnym. Zdaniem Jana Pawła II, wszyscy powinniśmy dążyć do tego, aby system gospodarczy, w którym żyjemy, nie burzył podstawowego porządku pierwszeństwa pracy nad kapitałem. Papież akcentuje, że społeczeństwo powinno szanować człowieka i jego pracę, ponieważ człowiek znaczy więcej przez to, że jest, niż że $\mathrm{ma}^{70}$. Pracodawca, mimo że jest właścicielem środków produkcji oraz ponosi ryzyko zatrudnienia pracownika, nie może instrumentalnie traktować pracownika.

W sytuacji, gdy rośnie bezrobocie, a pracodawcy domagają się liberalizacji prawa pracy, wzmocnienie ochrony godności oraz innych dóbr osobistych pracownika nie będzie łatwe. Dla osób, które znalezienie pracy postrzegają jako jedyną szansę na poprawę trudnej sytuacji materialnej, uzyskanie zatrudnienia jest o wiele ważniejsze niż szanowanie ich dóbr osobistych przez pracodawcę. Często wyrażają one świadomie zgodę na ingerencję $w$ ich prawo do prywatności czy też godzą się na instrumentalne traktowanie w miejscu pracy. L. Florek podkreśla jednak, że liberalizacja prawa pracy (m.in. umowna) nie może dotyczyć ochrony godności pracownika czy też jego prawa do prywatności ${ }^{71}$.

2. Obowiązek szanowania godności oraz innych dóbr osobistych pracownika to jedna $z$ podstawowych zasad polskiego prawa pracy (art. $11^{1}$ k.p.).

\footnotetext{
${ }^{70}$ Orędzie Jana Pawła II do świata pracy, opubl.: Niedziela 2000, nr 20, s. 5.

${ }^{71}$ L. Florek, „Granice liberalizacji prawa pracy” (referat wygłoszony na XIV Zjeździe Katedr (Zakładów) Prawa Pracy, Łódź, 28 V 2003 r.).
} 
Z kolei w prawie wspólnotowym ochrona godności oraz innych dóbr osobistych pracownika znajduje się niejako na drugim planie. Eksponuje się natomiast zasadę równego traktowania $\mathrm{w}$ zatrudnieniu. Wspólnotowe przepisy antydyskryminacyjne określają $m$.in. instrumenty prawne służace ochronie pracownika przed molestowaniem seksualnym.

3. Do naruszenia dóbr osobistych pracownika, o czym była wyżej mowa, dochodzi m.in. w związku z mobbingiem i molestowaniem seksualnym oraz $w$ związku $\mathrm{z}$ niezgodnym $\mathrm{z}$ prawem przetwarzaniem danych osobowych pracownika przez pracodawcę. Przepisy polskiego prawa pracy określają obowiązki pracodawcy $\mathrm{w}$ zakresie przeciwdziałania mobbigowi oraz obowiązi pracodawcy w zakresie ochrony interesów i praw pracownika, którego dane są przetwarzane w związku z zatrudnieniem. Nie sposób nie zauważyć, że na określenie w polskim prawie pracy zakresu tych obowiązków oraz konsekwencji ich naruszenia wywarły wpływ europejskie standardy. W związku z europeizacją polskiego prawa pracy nastapiły zmiany $\mathrm{w}$ przepisach statuujących te obowiązki. 
